\title{
Canadian Federalism in the Context of Combating Climate Change
}

\author{
Alexis Bélanger *
}

\section{Introduction}

Many people today describe Canada's policy on the environment as fragmented. Thus, for a number of years, there have been more and more calls for federal leadership in environmental matters. However, in the Canadian context, pondering the development of innovative public policy without also asking which level of government has the power to adopt and implement it is equivalent to circumventing the reality of Canadian federalism. Conversely, raising this question at times appears akin to introducing an irritant-the division of powers in the context of contemporary issues such as climate change can easily be perceived by some as a constitutional relic, an obstacle to overcome in the process of choosing the means to implement truly national, modern, and effective public policies.

Centralization appears, in the eyes of many, to be an obvious solution in the climate change dossier: provincial policies are viewed as a fragmented patchwork, a source of failure to act; the federal and provincial governments are caught in the trap of joint decision making; and the current system is packed with useless and costly structural duplications that undermine the efficiency and effectiveness of the policies. After many decades of a federal modus operandi that has led to generalized involvement in provincial fields of jurisdiction, for some, Canadian federalism is becoming a simple institutional idiosyncrasy to be accommodated to avoid conflict.
But in the past, by wanting to act hastily and with no thought to the division of legislative power, Canada has committed a certain number of errors-mistakes it would be better not to repeat in an issue as fundamental as that of climate change. The national energy policy was one such example. In reality, numerous aspects indicate that true federalism could actually constitute an asset in responding to the challenges of climate change. After defining the concepts of environment and federalism, this article attempts to place the evolution of, and the relationship between these concepts in recent political history and in the Canadian legal framework. This overview then demonstrates why, in the current context of combating climate change, and going beyond constitutional arguments, a single imposed policy on the entire Canadian federation is ill advised and detrimental to all other potential policies.

\section{Environmental Federalism (the principles)}

\section{The Concepts of Environment and Federalism}

The word "environment" primarily makes us think of all the surrounding conditions and influences that affect the development of a living organism. ${ }^{2}$ A concept that is multi-faceted and both wide-ranging and local, the environment has become the focus of public policy when the 
preservation of natural resources required for economic development has become imperative. Urbanization, the rapid industrialization of our societies, and the massive use of fossil fuel energy are the causes of another phenomenon central to the concept of the environment: pollution. In just a few decades, pollution and the overexploitation of natural resources have generated a number of complex problems, such as declines in marine biomass, forests, and biodiversity; climate change; and an overabundance of harmful chemical products in the environment. Problems that call for urgent action at all levels to protect the environment.

In June 1992, at the Rio de Janeiro Earth Summit, the international community conceptualized the environment as a "common good" or a "public good." An awareness emerged on an international political scale, that environmental problems cannot be separated from social and economic problems, leading to the concept of sustainable development, which encompasses all of these aspects.

Whereas the environment is a holistic concept, for its part federalism is based on the very concept of segmentation. ${ }^{4}$ Hence, within the Canadian framework, an added difficulty in legislating issues surrounding the environment, and more specifically climate change, arises from our perception of the environment, which is unitary and global, versus the nature of our federal structure, which advocates decentralization and the division of power. The fact that Canada is a federation has significant consequences on the manner in which we address environmental issues. ${ }^{5}$ The particular challenges posed by managing the environment within federal or quasi-federal structures have led to extensive scientific documentation on environmental federalism, chiefly dealing with European and U.S. cases. ${ }^{6}$

Federalism does not take the form of a single model. According to Henri Brun et al, this institutional system basically proposes a partial amalgamation to accomplish certain common tasks without sacrificing the autonomy of the components in other matters. ${ }^{7}$ For constitutionalist Peter Hogg, the genesis of the federal system in Canada arose from a political compromise among those in favour of a political union and those in favour of diversity. ${ }^{8}$ But the choice of a federal system for Canada was not a second-best solution: "the federal form of government has some distinctive advantages." Thus, according to Hogg, one of the main advantages of federalism remains its ability to take into account the different interests and preferences throughout the federation. Another significant advantage of Canadian federalism is the provinces' innovative capacities: "Provinces [...] being more homogenous than the nation as a whole, will occasionally adopt policies that are too innovative or radical to be acceptable to the nation as a whole. If a new programme does not work out, the nation as a whole has not been placed at risk. If the programme works well, it might be copied by other provinces or states, and perhaps (if the Constitution permits) by the federal government."

\section{The Division of Jurisdiction in Environmental Matters}

Protecting the environment was not a major concern in the nineteenth century; therefore it is easy to understand that this topic was not expressly mentioned as a specific aspect in the Constitution Act, 1867. Today, in case law, the environment is considered a domain that is not exclusively under the jurisdiction of one or the other level of government. In the Friends of the Oldman River ${ }^{10}$ judgment, the Supreme Court of Canada determined that each level of government can legislate in environmental matters when it is acting from the basis of one of its constitutional powers.

The constitutional foundation for the role of the provinces on environmental issues is based, in particular, on provincial ownership of natural resources and the jurisdiction that ensues. This confers important power pertaining to the environment on the provinces over anything affecting the sustainable development of these resources, for example. The provinces also have jurisdiction over crown land, property and civil rights, municipal institutions, and, more generally, matters of a local or private nature. These important constitutional foundations enable the provinces to intervene with respect to certain environmental issues using global 
approaches. The only reallimit to environmental action by the provinces, apart from the specific areas under federal jurisdiction, is the relative difficulty in addressing the cross-border aspect of pollution. However, even in this regard, several precedents illustrate how, in certain situations, the provinces and U.S. states are better able to resolve transboundary problems than federal authorities, in particular through the practice of interprovincialism and the implementation of the ensuing multiple agreements. For example, the provinces and states along the shores of the Great Lakes recently concluded the Great Lakes-St. Lawrence River Basin Sustainable Water Resources Agreement. ${ }^{11}$ Under this agreement, individual action by two Canadian provinces and eight U.S. states resulted in the harmonization of regulations on the management of Great Lake resources, and today it is helping maintain sustainable management of their waters.

For its part, federal jurisdiction is characterized by greater ambiguity. Although the Canadian Parliament has the power to legislate with regard to federal properties and works, its legislative authority in environmental matters remains largely indirect and limited. Consequently, a number of federal environmental policies are based on powers in specific areas such as the fisheries and navigation. Furthermore, in case law, some federal interventions in environmental matters have been grounded on the "national dimensions" doctrine and the federal jurisdiction over criminal law.

In 1988, in the case of $R v$ Crown Zellerbach, the Supreme Court recognized the validity of the federal provision prohibiting the dumping of waste into the sea. To do so, the majority based their decision on the matter falling within the national concern doctrine of the "peace, order and good government" clause. The Court concluded that no specifically enumerated federal jurisdiction enabled validation of the provision, but that control over ocean pollution met the test of this general doctrine. In examining this test, the Court considered among other issues that the failure of a province to deal effectively with the control of transboundary aspects of marine pollution would have a harmful im- pact on a Canadian and international scale.

In 1997, in the case of $R v$ Hydro-Québec, the Supreme Court, on the basis of federal jurisdiction under criminal law, considered the contested provisions of the Canadian Environmental Protection Act (CEPA) valid. This divided decision, enabling the development of regulatory schemes through jurisdiction over criminal law, has given rise to many questions in terms of its negative impact on the balance of powers within the federation. ${ }^{12}$ Since the HydroQuébec decision, the Supreme Court has recognized that too broad a definition of criminal law presents risks. Furthermore, it is interesting to note a certain reticence by the Supreme Court in the Hydro-Québec decision concerning the national dimensions doctrine, given its even greater impact on the balance of powers within Canadian federalism. For the Court, this latter doctrine cannot allow the Canadian Parliament to claim general power over protection of the environment.

\section{Relationships between Ottawa and the Provinces Regarding the Environment (in practice)}

In response to the emerging concerns of citizens about the initial visible impact of economic growth on the quality of the environment, the two levels of government mobilized at the end of the 1960s to implement the first real public policies on the subject. Also, in this context, in the name of the environment, the federal government first manifested the political desire to intervene in fields of jurisdiction that had been held exclusively by the provinces. ${ }^{13}$ However, the federal government's action remained relatively limited, and the strong resistance of the most populated provinces to these encroachments made it quickly retreat, preferring to support a more cooperative approach. ${ }^{14}$

This first period of tension was then followed by a period of relative decentralization in the mid-1970s. In this era, the Fisheries Act (section 33) constituted the principal justification for federal regulations pertaining to the environment. The federal Department of the 
Environment left the responsibility for applying and enforcing federal standards to the provinces. ${ }^{15}$ The federal government, however, maintained its role of developing those "national" standards.

In the early 1980s, several events helped accelerate a collective awareness of modernday environmental issues (Bhopal-1984; the discovery of a hole in the ozone layer-1985; Chernobyl-1986; a fire in a PCB storage facility in Saint-Basile le Grand-1988.) At the time, the development of a green plan with a \$3-billion budget by Brian Mulroney's federal government was an indication of the growing importance of the environment in Canadian public policy. The adoption of the Canadian Environmental Protection Act in 1988 and the Canadian Environmental Assessment Act in 1992 marked a significant change in the balance of federalprovincial relations regarding the environment, and the beginning of a new era of tension. With the Canadian Environmental Protection Act, Parliament considerably strengthened its own regulatory powers, particularly in the regulation of toxic substances, taking the "from cradle to grave" approach. ${ }^{16}$

In the same time period, the late 1980s saw the establishment of the first formal intergovernmental cooperation forum in environmental matters, the Canadian Council of Ministers of the Environment. Originally identifying itself as an alternative to federal unilateralism, this body soon became a co-optation platform of Canada-wide standards, which led to the negotiation of Canada-wide standards in 1996 and their subsequent adoption by all provinces except Quebec. This agreement provided a concrete structure for the division of tasks between Ottawa and the provinces, a model that is reflected in a number of other fields, in which the federal level reserves for itself the role of thinker, designer, and architect, and in which the provinces have the responsibility of implementing these federal policies while respecting a number of conditions ensuring consistency in the policies. This type of approach, although often drawing on provincial innovation, nonetheless curbs provincial capacity to innovate further by weakening policy flexibility and ignoring regional differences. This problem was recently demonstrated in the context of intergovernmental discussions towards the development of federal regulatory control over air pollutants and the adoption of a federal regulation that would impose on the provinces specific limits on the discharge of wastewater.

Over the course of the past decade, climate change has dominated a major part of the Canadian political debate on environmental matters, in particular the intergovernmental conflict surrounding adherence to the Kyoto Protocol and the terms of its implementation. The will of the federal government to centralize and lead climate change control has given rise to an important power brokerage game, despite the principle of federalism and distribution of powers. As a provincial senior public service official, cited by author Barry G. Rabe, has said: "The feds are going to every province and asking, 'What will it take to make this work?' For Saskatchewan, it's subsidies for clean coal research. For Manitoba, it's the promise of an electricity transmission line to Toronto. The assumption is that every province has its price and that you can buy them off." ${ }^{\prime 7}$ Also, according to this author, a significant part of the energy and resources of the provinces that are opposed to the ratification of Kyoto has been devoted to upping the bids and, at the end of the line, derailing the process of implementing Kyoto.

However, this conflict and the ensuing political impasse provided the provinces with the opportunity to take charge of combating climate change. They have consequently expanded and enhanced innovative measures to reduce greenhouse gas emissions, in particular. In this regard, the provinces benefitted from a notable change in approach by Ottawa under the governance of Paul Martin, who in 2005 made a commitment to support the various efforts of the provinces, a commitment that was partially fulfilled by Stephen Harper in February 2007.18 Under its eco-Trust program, Ottawa has allocated $\$ 1.5$ billion to provincial environmental initiatives.

This decision to promote relative decentralization has already shown results: announcements of ambitious provincial plans have been 
increasing since 2007 and often exceed federal proposals to combat climate change and adapt to the impact of these new initiatives. As one example among many, ${ }^{19}$ Quebec established royalties on the carbon content of gasoline and fossil fuels, a North American first. Shortly after, British Columbia adopted a carbon tax. Furthermore, Quebec was the first Canadian province to adopt greenhouse gas emission standards for motor vehicles aligned with those of California. What is more, with its partners from the Western Climate Initiative, Quebec is in the process of developing and implementing a common cap-and-trade system for emission allowances that would become the foundation for a future common carbon market in North America. ${ }^{20}$ Ontario, British Columbia, and Manitoba are also involved in the Western Climate Initiative, and are implementing comprehensive action plans that target most activities and the most important sectors. New Brunswick's objective is to bring emissions back to their 1990 level by 2012 and then to reduce them by an additional 10 percent of their 1990 level by 2020 .

The leadership shown to date by the provinces on the climate change front illustrates their ability to lead the way in combating climate change, based on powers attributed to them by the Constitution.

The federal government, itself, already has a broad scope of action within its given constitutional jurisdictions. Phenomenal environmental challenges must be addressed, especially in the area of sustainable management of the fisheries; public, military, and other supplies; federal works and undertakings; and interprovincial transportation. ${ }^{21}$ To cite one example, it appears somewhat paradoxical that the federal government is seeking to expand its control capacity to domains that are not under its jurisdiction while interprovincial railways, which are essentially its responsibility (para. 92 (10) (a) of the Constitution Act, 1867), suffer from chronic technological underdevelopment and a minimal service offer. Greater use of this form of transportation for moving both people and merchandise could significantly contribute to the reduction of greenhouse gases in Canada. The procrastination surrounding the construc- tion of a high-speed rail line in the QuebecWindsor corridor illustrates the extent to which certain sectors of federal jurisdiction, which require attention from an environmental point of view, could greatly benefit from more sustained political activity. ${ }^{22}$ Federal environmental policy could also take on a more structuring nature by setting the example rather than trying to control.

\section{Patchwork or Tapestry? (the debate)}

In its Climate Change Plan, published in 2007 along with the Kyoto Protocol Implementation Act, the federal government stated that: "Provinces, territories and municipalities control many of the important levers for making significant reductions in greenhouse gas emissions from particular sectors. [...] Over $85 \%$ of Canada's total greenhouse gas emissions is emitted in areas under sole or partial provincial/territorial responsibility." ${ }^{23}$ It is precisely in this context that most of the provinces and territories have expanded measures to reduce greenhouse gases.

Nonetheless, a little less than two years later, the National Round Table on the Environment and the Economy (NRTEE), a federal government advisory body whose mission is "to play the role of catalyst in identifying, explaining and promoting, in all sectors of Canadian society and in all regions of Canada, principles and practices of sustainable development"24 published a report on a possible Canadian carbon tax. In the initial pages the report states: "Our collective challenge now is to transition the emerging fragmentation of current carbon pricing policies to a unified policy framework across all emissions nationally. The negative consequence of not doing this, and maintaining this fragmentation of differentiated carbon prices across emissions and across jurisdictions, will be significantly higher economic costs, intensified environmental impacts, entrenched barriers that will make it harder to act in the future, and the real risk of not being able to meet Canadian emission reduction targets." ${ }^{25}$

Should it be concluded from these two statements that the provinces are responsible for the 
vast majority of carbon emissions but are not the best placed to develop policies targeting the reduction of these emissions, despite the fact that they control "many of the important levers" enabling such reductions? If the past is any indication of the future, "to transition the emerging fragmentation of current carbon pricing policies to a unified policy framework" could stifle the innovation and drive at work within Canadian provinces by imposing a single solution on a country-wide scale, obtained at the cost of expensive efforts and numerous compromises, which would very likely be accompanied by delay tactics. This has been the experience with the current federal plan on air quality and climate change: Turning the Corner, ${ }^{26}$ which is still not implemented more than four years after its announcement.

Canada has a relatively decentralized federal structure, which allows the diversity of its population and geography to be taken into consideration through the existence of autonomous governments that are much closer to citizens and their concerns. The Canadian experience, similar to that of other federations, should dissipate the fears expressed by the NRTEE and show to the contrary that federalism is an asset in combating pollution and protecting the environment. Rather than visualizing a patchwork, which gives the impression of a fragmented, heterogeneous arrangement, let us apply the metaphor of a tapestry in which various patterns are skilfully combined to produce a unit whose quality exceeds the sum of its parts. In this regard, Bob Page, chair of the NRTEE, stated when speaking of a plan to establish carbon pricing: "[F]lexibility is a key to our success because we are unlikely to get it right the first time."27

\section{The Position of Environmental Groups}

Historically, many Canadian environmentalists, surprisingly, have perceived the provinces as environmental ignoramuses and have demonstrated greater confidence in the federal government. ${ }^{28}$ This point of view appears to be based on the assumption that the Canadian federal government is synonymous with progressive public policy. As seen above, when the environmental balance sheet of recent years is examined, this assumption falls short of the facts. Not only that, such an assumption is inconsistent with the concept of the citizen movement and local action, on which the environmental movement calls. Strengthening local powers, for which the provinces are constitutionally responsible, appears in this regard to be a much more promising avenue, much more in line with these objectives.

It appears paradoxical that both industrial lobbies and environmental groups argue in favour of greater centralization of environmental power and the policies that ensue in Ottawa. This position is more consistent with some of the interests defended by major industrial groups.

\section{Adaptability and Proximity to Citizens}

Provincial leadership in combating climate change appears desirable in principle, to the extent that reaching political compromise is generally less complex at the provincial level than at the federal, as evidenced in the thorny Kyoto Protocol file. It is also precisely for this reason that the most ambitious Canadian social policies have been developed at the provincial level (in particular, universal health insurance and the subsidized daycare program). ${ }^{29}$

Geographical and environmental characteristics vary immensely in Canada, from one region to another and from one province to another. Canada occupies one of the largest land masses in the world. Climate change could cause an increase in the frequency or intensity of certain meteorological phenomena as vastly different as heat waves, downpours, droughts, floods, the melting of glaciers, and the thawing of permafrost. However, Canada has a federal structure capable of managing a vast territory characterized by diversity in its geographical environments. The diversity of ecosystems calls for diversity in environmental responses. Environmental standards must be adapted to the numerous local contexts in order to have their full effect. This is also why one-size-fits-all policies can often prove to be costly and inefficient. They are rarely optimal in a country as diversified as ours, particularly in environmental mat- 
ters. Reaching a consensus is often based on determining the smallest common denominator, to the detriment of more relevant, progressive, and stringent policies. Furthermore, in terms of climate change, the deepening and current economic imbalance among the provinces fed by energy prices, an issue that is itself related to the control of carbon emission, makes any Canada-wide compromise very difficult at best, if not impossible.

It might be preferable to see a majority of the provinces adopt diverse but bold measures such as carbon taxes or participating in regional carbon credit trading systems and let those implacably opposed to this type of measure develop their own solutions rather than mobilize all resources to decide on a single weak and ineffective Canada-wide policy, likely doomed for failure. As the publication Hot Air: Meeting Canada's Climate Change Challenge illustrates, all of the federal plans to combat climate change have not only failed but also futilely engaged numerous resources in their preparation and production. ${ }^{30}$ The implementation of the environmental policies emanating from these plans requires significant organizational resources, especially for analysis, evaluation, and inspection. This thus diverts the attention of the experts towards an often illusory quest for a Canadian consensus in a context in which defending the interests of each prevails, paralyzing action, rather than encouraging a profusion of innovative solutions. And, despite all of these efforts, the federal government's principal achievements in the area of combating climate change to date are limited to the often low-profile preparation and posting of costly reports. Thus, despite statements of conviction by federal politicians and successive green plans in Ottawa, greenhouse gas emissions have not stopped increasing. In 2008, they exceeded the level of Canada's commitments with respect to the Kyoto Protocol by more than 30 percent. ${ }^{31}$

On the whole, when developing measures to protect the environment, difficult decisions ensuring the fragile balance between social factors and economic development are more easily taken at the local level. ${ }^{32}$ Consideration of this factor is vital when introducing unpopular policies (for example, a new tax). Beyond the merit of the various measures, political capacity to implement policies that lack public support could prove to be a fundamental determinant of success in combating climate change.

\section{Innovation/Testing}

The release of excessive amounts of greenhouse gases into the atmosphere causes our societies to face a wide variety of complex and completely new challenges, for which the most effective solutions, for the most part, still remain to be developed. Hence, our ability to control climate change could be determined in large part by our ability to innovate, in terms of both technology and public policy.

A study of the factors conducive to innovation in a knowledge-based society has shown the fundamental importance of local knowledge as the determinant of a government's ability to innovate. As Globe and Mail journalist David Mitchell recently wrote: "Where all think alike, no one thinks very much. [...] Canada is a federation-the most creative public policy is found at the provincial level of the government, not the federal." ${ }^{33}$ To attain a certain maturity in the development of our policies, it appears to be essential to support local innovation across the country, which federalism encourages. In this regard, universities and research play an essential role, especially when they are well-rooted in the territories involved; this can constitute a priceless asset for sustainable development and the development of environmental policy adapted to realities in the field.

The environment, and especially efforts to combat climate change, requires public interventions that affect every aspect of society. The environment not only encompasses physical, economic, and social dimensions but also transcends global and local issues. In many ways, the development of innovative environmental policies has just begun. It is critical that, in this context and with our federal framework, the central government not consider the provinces as simple agents for implementing national policies but rather as veritable laboratories for the development of solutions adapted to local realities. 


\section{Carbon Tax (an example)}

The concept of a carbon tax effectively illustrates how federalism can contribute to the development and implementation of innovative policy. Many people believe that such a tax remains the most inexpensive way to collectively attain our goals in reducing greenhouse gases. ${ }^{34}$ In Canada, provincial governments introduced (British Columbia and Quebec) this ambitious policy. ${ }^{35}$

Yet, today, numerous voices are demanding strong federal leadership that will put some "order" in this "patchwork" of emerging policies across Canada. Stéphane Dion's proposal for a federal carbon tax presented during the 2008 electoral campaign came in part from this desire to see the federal government play a greater role in an area the provinces have begun to cover. The aforementioned NRTEE report also falls within this shift and thereby seeks to give a leading role in this policy issue to the federal government. The innovative role of the provinces to combat climate change appears once again about to be eclipsed by the perpetual search for the best solution with a view to setting a Canada-wide policy.

Arguments are already being advanced to lay the groundwork for the federal government eventually taking control of this new source of revenue. As an example, some suggest that constitutional jurisdiction over carbon tax can be based on criminal law, federal jurisdiction over trade and commerce, or a centralist reinterpretation of federal power to conclude and implement treaties. ${ }^{36}$ However, justifying the regulation of carbon based on these heads of power would be a real constitutional Trojan horse. Carbon is essentially omnipresent; every human and animal activity is a source of carbon emission. There is no single dimension of our societies that is not affected directly or indirectly by carbon emission. Direct intervention in the environment by the federal government, under the guise of general jurisdiction over climate change or air quality, would contribute to the excessive centralization of legislative powers in Canada. In this policy area, certain provinces such as Quebec have already adopted standards on greenhouse gas emissions that affirm provin- cial legislative power in the field. ${ }^{37}$ In addition, the establishment of an ambitious federal policy on carbon taxation would very likely give rise to intensive bargaining. Given the current geopolitical and economic context, certain industries would be extremely likely to be exempted and all of the provinces would undoubtedly claim equivalent exemptions in the name of intergovernmental equity, thereby greatly reducing the effectiveness of the tax. ${ }^{38}$ The main cause contributing to the reduced effectiveness of the system of carbon taxation levied in Norway, one of the pioneers in this arena, was just that: the numerous exceptions granted to various industries. ${ }^{39}$ The recent constitutional invalidation of the carbon tax in France was also justified by the excessive number of industries exempted from its application, which would have prevented the desired goal from being attained: to reduce greenhouse gas emissions.

The groups that support the implementation of direct carbon taxation as the simplest and least expensive way to control climate change should logically support its handling by provincial powers, because the desire to see this policy gain Canada-wide support that would enable centralized handling in Ottawa strongly risks clashing with political reality.

\section{Global Lessons for Local Empowerment}

During a visit to the Chinese city of Xi'an on 25 July 2009, the Secretary General of the United Nations, Ban Ki Moon, declared that: "National governments can have their national policies, but after all it is provincial governments who have to implement these policies and even from this kind of bottom-up support, policies will be much more effective than top-down policies." ${ }^{40}$ For several years, some observers have been proposing the establishment of a world federalism of policies on climate, which is seen as preferable to the centralized Kyoto approach. ${ }^{41}$ Noting this reality, the international community is organizing itself, and initiatives such as the Local Government Climate Roadmap are enabling a group of territories and federal states to emphasize their key role in the negotiation of a new planetary agreement on greenhouse gas reduction in 2012, the deadline foreseen in the Kyoto 
Protocol. This new approach favouring decentralization may prevail in the wake of the failure of the Copenhagen Summit. Furthermore, continental institutions, such as the North American Free Trade Agreement (NAFTA), the European Union (EU), and the Asia-Pacific Economic Cooperation (APEC), are considered to be more capable of responding to adaptation issues that will take on increasing importance in the future. ${ }^{42}$

In 2008, the United Nations Development Programme (UNDP) established a cooperative program targeting climate change titled, "Towards Carbon Neutral and Climate Change Resilient Territories." For the UNDP, the capacity for action among federated states in combating climate change is undeniable, and this is why it is seeking the cooperation of developed federated entities to help developing federated entities and regional governments with their climate change mitigation and adaptation strategies. Moreover, the UNDP solicited the participation of Quebec in this innovative partnership, precisely because of the particular expertise the province has developed.

\section{Conclusion}

Diversity should not be viewed as synonymous with chaos-far from it. Such a reaction reflects the old habit of viewing environmental policies from the perspective of centralization whereas regional approaches are gaining increasing importance and notice. The most common criticism levelled at decentralized initiatives is that they do not guarantee the attainment of global objectives. However, as Canadian federal policies for combating climate change and, on a larger scale, the worldwide Kyoto effort have demonstrated, the centralized alternative has not been characterized by success. Although the decentralized approach must not be viewed as capable of meeting all the challenges posed by climate change, it should be of greater appeal to the political and academic elite who have examined and analyzed a univocal approach that may have reached its limits. In brief, on an international scale, as on the Canadian scale, one reality stands out: environmental challenges call for new forms of governance. Exercising feder- alism can facilitate this transition. Above all, it enables the advantages emanating from centralization and decentralization to be balanced.

Much is to be gained from taking advantage of the diversity of political solutions developed across Canada, rather than impose a national policy, which would inevitably produce friction given the vast number of divergent interests within the federation. Until now, the intergovernmental conflict surrounding adherence to the Kyoto Protocol and the conditions for its implementation have dominated too much of the Canadian political debate on climate change. It is preferable to use all of the resources available to develop and test various formulas in seeking the best possible combination of public policies based on different local and regional realities. Instead of a centralized approach, the federal government should work in partnership with the provinces to undertake activities to complement provincial initiatives, thereby maximizing the impact of environmental action.

New strategies must be adopted to face new challenges. To address increasingly urgent environmental problems, the federal government and its supporters must set aside their centralist reflexes and encourage the provinces to continue experimenting. Ottawa must, at the same time, fulfill its environmental responsibilities in its own fields of jurisdiction, for the greatest benefit of both federalism and the environment.

\section{Notes}

* The author is a policy analyst with the Department of Intergovernmental Affairs, government of Quebec. The views expressed herein are those of the author in his personal capacity. They do not necessarily reflect the position of the government of Quebec.

2 Gage Canadian Dictionary, 1998, sub verbo "environment".

3 Report of the United Nations Conference on Environment and Development, Rio de Janeiro, 1992 (UNA/CONF 151/26 (vol 1)), online: $<$ http://www.un.org/documents/ga/conf151/ aconf15126-1annex1.htm>.

$4 \quad$ Jean Leclair, "L'étendue du pouvoir constitutionnel des provinces et de l'État central canadiens en matière d'évaluation des incidences environnementales" in Hélène Trudeau \& Ejaan 
Mackay, L'environnement: À quel prix? (Éditions Thémis: Montreal, 1995) at 345.

5 Douglas Brown, “The Environmental Union” in Herman Bakvis, Gerald Baier \& Douglas Brown, Contested Federalism (Ontario: Oxford University Press, 2009) at 207.

6 David Vogel et al, "Environmental Federalism in the European Union and the United States" (Paper delivered at the Conference on Globalization and National Environmental Policy, 22-24 September 2003) online: Tilburg University < http://www.tilburguniversity.edu/>.

7 Henri Brun, Guy Tremblay \& Eugénie Brouillet, Droit constitutionnel, 5th ed (Cowansville, Que: Yvon Blais, 2008) at 404.

8 Peter Hogg, Constitutional Law of Canada (Canada: Carswell, 2007) at 5-14.

$9 \quad$ Ibid.

10 Friends of the Oldman River Society $v$ Canada (Minister of Transport), [1992] 1 SCR 3. See also André Prévost, "L’environnement estil un domaine de compétence provinciale?" in Développements récents en droit de l'environnement (Cowansville, Que: Yvon Blais, 1996).

11 Great Lakes-St Lawrence River Basin Sustainable Water Resources Agreement, online: Gouvernement du Quebec <http://www.mddep. gouv.qc.ca/eau/grandslacs-en/2005/index.htm>.

12 Louis-Raphaël N Lescop, "R c Hydro-Québec: la dénaturation du droit criminel au bénéfice de l'environnement" (1999) 33:2 RJT 421, online: Editions Themis $<$ www.themis.umontreal.ca/ pdf/rjtvol33num2/lescop.pdf $>$.

13 Duncan Maclellan, "Shifting From the Traditional to the New Political Agenda: The Changing Nature of Federal-Provincial Environmental Relations" (1995) 25:2-3 American Review of Canadian Studies 323.

14 Luc Juillet, "Le fédéralisme et l'environnement" in Manon Tremblay, Les politiques publiques canadiennes (Presses de L’université Laval, 1998) at 191 [Juillet].

15 Kathryn A Harrison, Passing the Buck: Federalism and Canadian Environmental Policy (Vancouver: University of British Columbia Press, 1996) at 81.

16 Juillet, supra note 14.

17 Barry G Rabe, "Climate Change Policy and Regulatory Federalism: The Divergent Paths of Canadian Provinces and American States in Greenhouse Gas Reduction" (Speech delivered at the Annual Meeting of the American Political Science Association, Washington, DC, 1-5 September 2005) at 15, online: All Academic
$<$ www.allacademic.com/meta/p_mla_apa research_citation/0/4/1/0/5/p41058_index.html>.

18 See Prime Minister of Canada, News Release, "Prime Minister Harper announces new ecoTrust Canada" (12 February 2007) online: Prime Minister of Canada <http://www.pm.gc.ca/ENG/ media.asp?id=1533>.

19 See especially Dale Marshall, Provincial Power Play: Breaking Away from Federal Inaction on Climate Change (Vancouver: David Suzuki Foundation, 2008), online: David Suzuki <http:// www.davidsuzuki.org/publications/reports/2008/ provincial-power-play-breaking-away-fromfederal-inaction-on-climate-change/index.php $>$.

20 See online: Western Climate Initiative $<\mathrm{http}: / /$ www.westernclimateinitiative.org $\geq$.

21 See e.g. online: Clean Technica <http:// cleantechnica.com/2009/08/01/army-going-solarwith-500-mw-of-solar-power-in-mojave-desert/> (the U.S. army recently launched the most far-reaching solar energy project in the United States).

22 See e.g. online: Canadian Political Science Association <http://www.cpsa-acsp.ca/ papers-2009/Bird.pdf >. (in which a Canadian researcher holds that VIA Rail is a rail service provider that is not offering quality service to travellers. This decline in services is not due to the quality of the company's management, but is rather the result of constraints created by the federal government and Canadian National).

23 Government of Canada, "A Climate Change Plan for the Purposes of the Kyoto Protocol Implementation Act - 2007" (6 September 2007), online: Environment Canada <http://www.ec.gc. ca/doc/ed-es/p_123/s5_eng.htm $>$.

24 National Round Table on the Environment and the Economy (7 February 2011), online: nrteetrnee $<$ http://www.nrtee-trnee.com/fra/a-notresujet/qui-nous-sommes.php $>$.

25 National Round Table on the Environment and the Economy, Achieving 2050: A Carbon Pricing Policy for Canada, online: nrtee-trnee <http:// www.nrtee-trnee.com/eng/publications/carbonpricing/carbon-pricing-advisory-note/carbonpricing-advisory-note-eng.pdf >.

26 Government of Canada, Turning the Corner: An Action Plan for Reducing Greenhouse Gases and Air Pollution (26 April 2007), online: Environment Canada $<$ http://www.ec.gc.ca/ default.asp?lang=En\&n=4891B242-1>(the approach targeted by this action plan leaves a lot of room for stalling tactics and accommodations, which reduce both scope and efficiency. Readers may recall that beginning the day after the 
unveiling of this framework, the Opposition and environmentalist groups - who were joined by Al Gore - unanimously denounced the ineffectiveness and timidity of the measures put forward in this document).

27 Bob Page, "Climate Change, Carbon Pricing, and Environmental Federalism" (Paper delivered at the Carbon Pricing and Environmental Federalism Conference, Institute of Intergovernmental Relations, Queen's University, Ontario, 17 October 2008), online: Queens University $<$ http://www.queensu.ca/iigr/conf/ EnviroConference2008/Materials/PagePaper. pdf $>$.

28 Kathryn A Harrison, "Passing the Environmental Buck" in François Rocher \& Miriam Catherine Smith, New Trends in Canadian Federalism (Ontario: Broadview Press, 2003) at 323.

29 See P Manna, School's In: Federalism and the National Education Agenda (Washington, DC: Georgetown University Press, 2006) (which provides an example of this same dynamic in U.S. federalism).

30 Mark Jaccard et al, Hot Air: Meeting Canada's Climate Change Challenge (Toronto: Douglas Gibson Books, 2007).

31 Scott Vaughan, "March 2009 Status Report of the Commissioner of the Environment and Sustainable Development" (21 April 2009), online: Office of the Auditor General of Canada $<$ http://www.oag-bvg.gc.ca/internet/English/ osh_20090421_e_32489.html>.

32 Pierre Brun, "La pollution du partage des compétences par le droit de l'environnement" (1993) 24 RGD at 191.

33 David Mitchell, "Vive la différence! Our spending mosaic makes us stronger", The Globe and Mail (27 April 2009).

34 See e.g. the "Pigou Manifesto" (a document on the economic efficiency of carbon taxation, signed by economists from all ideological outlooks: Gregory Mankiw, Paul Krugman, Gary Becker, Alan Greenspan, Anthony Lake, Thomas Friedman, Lawrence Summers, Paul Volcker, Jeffrey Sachs, William Nordhaus and many others), online: Pigou Club $<$ http://www. pigouclub.com/>.

35 See "Taxe carbone: les exemples à l'étranger" (8 March 2009), online: Le Monde <http://www. lemonde.fr/planete/article_interactif/2009/08/03/ taxe-carbone-les-exemples-a-1etranger_1223975_3244_6.html>.

36 For a summary of these arguments, see Stewart Elgie, "Kyoto, The Constitution, and Carbon
Trading: Waking a Sleeping BNA Bear (or Two)" (2008) 13:1 Rev Const Stud 67. See also Shi-Ling Hsu \& Robin Elliot, "Regulating Greenhouse Gases in Canada: Constitutional and Policy Dimension" (2009) 54 McGill LJ at 463.

37 See the Regulation respecting greenhouse gas emissions from motor vehicles, RSQ, c Q-2, $\mathrm{r}$ 6.001 .

38 See e.g. "Les gaz a effet de serre au menu", RadioCanada (9 September 2009), online: RadioCanada <http://www.radio-canada.ca/regions/ Ontario/2009/09/09/006-bourse-carbone-qcon.shtml > (describes the joint statement by premiers McGuinty and Charest following the joint Ontario-Quebec ministers' council, with greenhouse gases on the agenda).

39 Aneegrete Bruvoll \& Bodil Merethe Larsen, "Greenhouse Gas Emissions in Norway-Do Carbon Taxes Work?” (2002) 337 Statistics Norway Discussion Papers.

40 "UN Secretary General requests closer co-operation between local and national governments", Local Government Climate Roadmap (25 July 2009), online: Climate Roadmap <http://www.iclei.org/index. php?id=10228>.

41 David G Victor, "Climate Accession Deals: New Strategies for Taming Growth of Greenhouse Gases in Developing Countries" in Joe Aldy \& Rob Stavins, eds, Post-Kyoto International Climate Policy: Implementing Architectures for Agreement (Cambridge University Press, 2010).

42 Philippe Le Prestre, "Géopolitique régionale du climat et coopération internationale" (2009) 1:6 Les Cahiers de l'institut EDS. 